\title{
Nitrate and phosphate uptake characteristics of three species of brown algae cultured at low salinity
}

\author{
Francisco J. L. Gordillo*, Matthew J. Dring, Graham Savidge \\ Queen's University Marine Laboratory, The Strand, Portaferry, Co. Down, BT22 1PF, United Kingdom
}

\begin{abstract}
Nitrate and phosphate uptake mechanisms have been characterised under conditions of 100 and $50 \%$ seawater in 3 common brown algae of NW Europe: Fucus vesiculosus, F. serratus and Laminaria digitata. Under low salinity, the growth rate and internal nitrate accumulation of $F$. serratus significantly increased ( 20 and $48 \%$, respectively), but no significant changes were observed for $F$. vesiculosus and L. digitata. However, nitrate uptake rates were reduced in L digitata, so that this species was less adaptable to low salinity than the Fucus species. Both F. vesiculosus and F. serratus reached a steady-state uptake rate after acclimation regardless of the salinity treatment. All 3 species had a high capacity for storing inorganic N and P intracellularly. The results for F. serratus pointed to a dual mechanism of adaptation to the special characteristics of the intertidal environment where it grows. Non-saturating (low affinity) nitrate uptake and biphasic (double Michaelis-Menten curve) phosphate uptake are adaptations to high nutrient concentrations. Temporal partition of cellular energy for carbon metabolism and nutrient uptake is also suggested as an adaptation to the transient nutrient inputs occurring in these environments.
\end{abstract}

KEY WORDS: Salinity $\cdot$ Nitrate $\cdot$ Phosphate $\cdot$ Uptake $\cdot$ Intertidal environment $\cdot$ Photoperiod $\cdot$ Fucus serratus $\cdot$ Fucus vesiculosus $\cdot$ Laminaria digitata

\section{INTRODUCTION}

Some species of Phaeophyceae, in particular species of the genera Fucus and Laminaria, dominate large portions of the intertidal and subtidal zones of the North Atlantic coastal regions, an environment that is characterised by periodic fluctuations of several ecological variables during the tidal cycle. Some of these species form extensive communities even in estuaries, where the typical marine environment is heavily modified by reduced salinity. Vertical salinity gradients in the surface layers may be pronounced, and in areas with regular tides, periodic flushing of water occurs, creating variable salinity regimes, while both rainfall and evaporation may cause large and irregular chan-

\footnotetext{
*Present address: Departamento de Ecología, Facultad de Ciencias, Universidad de Málaga, Campus Teatinos, 29071 Málaga, Spain. E-mail: gordillo@uma.es
}

ges in ambient salinity in the algal beds during low tide (Russell 1987a).

Fluctuations in salinity result in marked physiological and biochemical changes in the plants (Munda 1964, Rueter \& Robinson 1986), which may affect growth (Strømgren 1994). Typical estuarine algae can tolerate low salinity conditions better than strictly marine species, while intertidal species have a broader salinity tolerance than sublittoral species (Khfaji \& Norton 1979, Yarish \& Edwards 1982, Hanisak \& Samuel 1987, Russell 1987b). Pulsed run-off of nutrients in coastal areas can lead to nitrate concentrations above $50 \mu \mathrm{M}$ (Sharp 1983). Thus, it is possible that salttolerant macroalgae have different strategies for nutrient uptake. In coastal phytoplankton, biphasic uptake kinetics (one operating at low and another at high nutrient concentrations) as well as non-saturating kinetics have been described as adaptations to pulsed high nutrient inputs (Lomas \& Glibert 1999). Nonsaturating nutrient uptake kinetics have also been ob- 
served in macroalgae (Wallentinus 1984), but how sessile intertidal macroalgae take advantage of these episodic events is poorly understood.

Tolerance to low salinity has made the macroalgae of such habitats promising candidates for the removal of nutrients from local wastewater. The idea of using simple tanks or ponds with a mixture of wastewater and seawater containing macroalgae for small-scale purification has proved encouraging (DeBusk et al. 1986, Vandermeulen \& Gordin 1990, Haglund \& Pedersen 1992, Haglund \& Lindström 1995). It has long been recognised that mass culture of algae in wastewater can significantly contribute to the management of freshwater ecosystems by providing a more environmentally sound approach to reducing the eutrophication potential than is achieved by conventional treatment practices. But the nutrient physiology of macroalgal species must be known before money and scientific effort are invested in developing pilot plants (Haglund \& Lindström 1995).

In this paper we present the nitrate and phosphate uptake characteristics of common species of NW Europe cultured under conditions of reduced salinity. The species and treatments used were selected also to explore the possible use of such species for year-round wastewater treatment in these latitudes. The ecological significance of the mechanisms described are discussed.

\section{MATERIALS AND METHODS}

Plant material. Vegetative plants of Fucus vesiculosus L., F. serratus L. and Laminaria digitata (Huds.) Lamouroux were collected in Strangford Lough (Northern Ireland). The upper branches of Fucus species

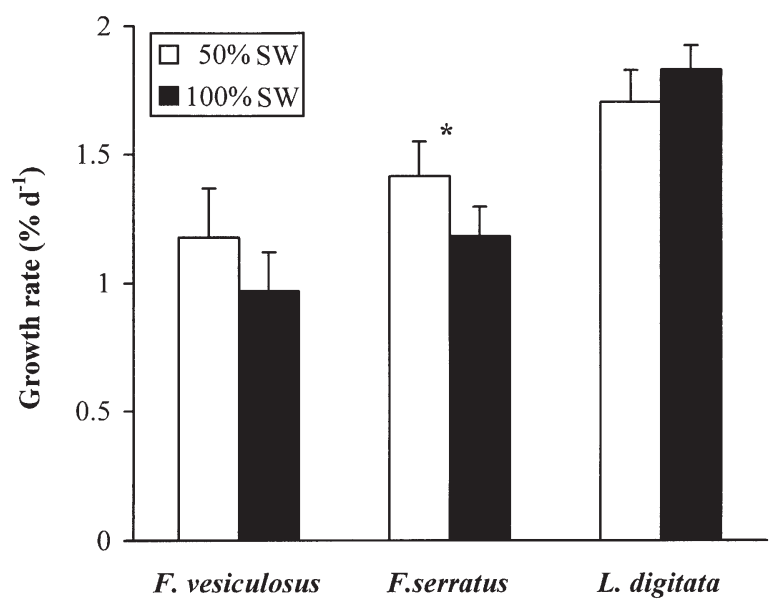

Fig. 1. Relative growth rate in fresh weight (FW) of Fucus vesiculosus, F. serratus and Laminaria digitata cultured for 3 wk in $50 \%$ and $100 \%$ seawater (SW). * Significant differences $(t$-test, $\mathrm{p}<0.05)$. Data are mean $\pm \mathrm{SD}(\mathrm{n}=3)$ plants and lower blade regions of $L$. digitata plants were selected from healthy thalli free from macroscopic epibiota. All thallus pieces were about $10 \mathrm{~g}$ fresh weight $(\mathrm{FW})$.

Experimental conditions. Standard cultures of the seaweeds consisted of $10 \mathrm{l}$ tanks containing a biomass density of $5 \mathrm{~g} \mathrm{FW}^{-1}$. The medium was aerated at 11 $\mathrm{min}^{-1}$ and illuminated by cool-white fluorescent lamps at $100 \mu \mathrm{mol}$ photons $\mathrm{m}^{-2} \mathrm{~s}^{-1}$. The photoperiod was $10 \mathrm{~h}$ light:14 $\mathrm{h}$ dark and the temperature was $15 \pm 2{ }^{\circ} \mathrm{C}$. Except where otherwise indicated, $\mathrm{NaNO}_{3}$ and $\mathrm{H}_{2} \mathrm{NaPO}_{4}$ were added in batch mode at the beginning of the experiments to give initial concentrations of 100 and $5 \mu \mathrm{M}$, respectively. The 2 nutrients were then added daily throughout the culture period to restore concentrations close to the initial values.

To investigate the uptake of nitrate and phosphate at low salinity, plants were cultured for $3 \mathrm{wk}$ in $50 \%$ filtered seawater (Whatman GF/F) and $50 \%$ distilled water, with a control consisting of cultures in $100 \%$ filtered seawater. Prior to the experiments, plants were kept under these conditions for $3 \mathrm{~d}$ to reduce the influence of osmoregulatory processes on FW and uptake mechanisms, which are known to occur in the first hours of acclimation to low salinity (Bäck et al. 1992). Three independent tanks were set up for each treatment and each species. Water samples were taken at increasing intervals from $1 \mathrm{~h}$ to $6 \mathrm{~d}$ following the first addition of nutrients to pre-adapted cultures. Tissue samples were collected at the beginning and at the end of the 21 d culture period, in order to measure internal nitrate and phosphate concentrations as described below, and growth was calculated from the increase in FW measured every $3 \mathrm{~d}$.

The influence of the external concentrations of nitrate and phosphate on the uptake of these nutrients was investigated in Fucus serratus pre-adapted to $50 \%$ seawater and nutrient sufficiency. Individual blades of $1 \mathrm{~g}$ FW were transferred from the culture tanks in the middle of the light period into $125 \mathrm{ml}$ glass bottles at a saturating irradiance $\left(500 \mathrm{mmol} \mathrm{m} \mathrm{m}^{-2} \mathrm{~s}^{-1}\right)$ and aerated at $0.251 \mathrm{~min}^{-1}$. External concentrations at the beginning of the incubations ranged from 10 to $1000 \mu \mathrm{M}$ for nitrate and 2 to $200 \mu \mathrm{M}$ for phosphate $(\mathrm{N}: \mathrm{P}=5)$. Incubation times increased from 30 min for the lowest concentration to $3 \mathrm{~h}$ for the highest. Different incubation times were needed in order to obtain final concentrations within the range suitable for the analytical method (described below) (Wallentinus 1984).

Growth and the uptake of nitrate and phosphate by Fucus serratus were investigated in photoperiods of $6 \mathrm{~h}$ light:18 h dark, $10 \mathrm{~h}$ light:14 h dark, $14 \mathrm{~h}$ light:10 h dark and $18 \mathrm{~h}$ light: $6 \mathrm{~h}$ dark. Plants were cultured for $4 \mathrm{~d}$ in $10 \mathrm{l}$ tanks under the standard conditions described above, following pre-adaptation to the experi- 

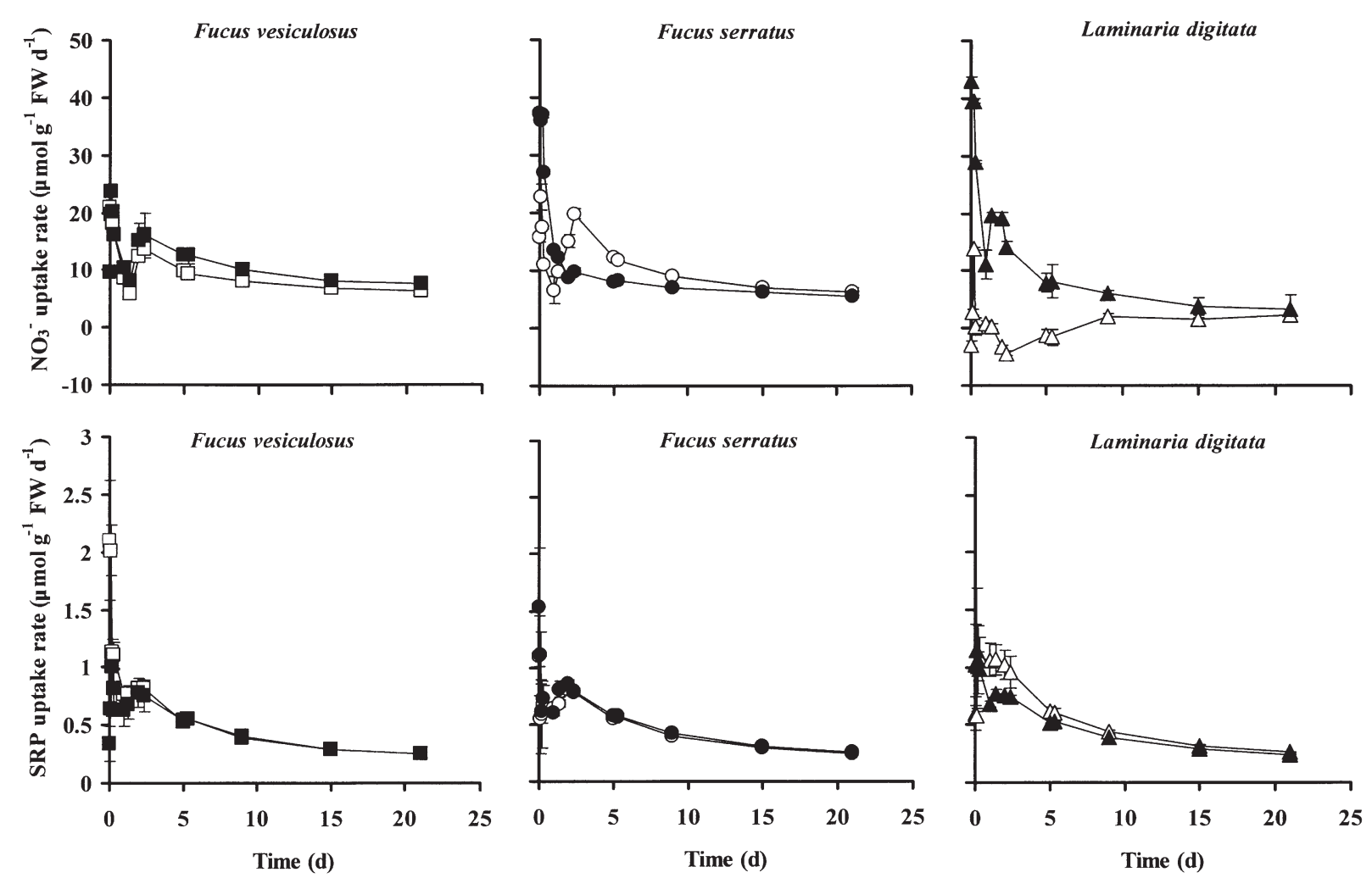

Fig. 2. Rates of uptake of nitrate (upper panels) and phosphate (soluble reactive phosphate [SRP]; lower panels) from the external medium by Fucus vesiculosus $(\boldsymbol{\square}, \square)$, F. serratus $(\boldsymbol{\bullet}, 0)$ and Laminaria digitata $(\boldsymbol{\Lambda}, \Delta)$ cultured in $50 \%$ SW (open symbols) and $100 \%$ SW (closed symbols). Daily additions of both nutrients were made to bring concentrations back up to the original (100 $\mu M$ $\mathrm{NO}_{3}{ }^{-}$and $5 \mu \mathrm{M}$ SRP). Data are mean $\pm \mathrm{SD}(\mathrm{n}=3)$

mental photoperiod for $3 \mathrm{~d}$ before the experiment began. The water was sampled daily and uptake rates were calculated as the decrease in nutrient concentration over the $4 \mathrm{~d}$ period.

The diel pattern of uptake was also investigated in Fucus serratus pre-adapted and cultured in $10 \mathrm{l}$ tanks with $50 \%$ seawater. Water samples were taken every $2 \mathrm{~h}$, and the experiment was run for $4 \mathrm{~d}$.

Determination of nitrate and phosphate. Nitrate and soluble reactive phosphate (SRP) concentrations were analysed in an automated nutrient analyser (Bran and Luebbe AA III) using the manufacturer's protocols. Nitrate determination was based on Wood et al. (1967), and that of phosphate on Murphy \& Riley (1962). Water samples were filtered (Whatman GF/F) after collection from the tanks and stored at $-20^{\circ} \mathrm{C}$ until analysis. Internal concentrations were measured in extracts from dried algal material $\left(80^{\circ} \mathrm{C}\right.$, overnight). After grinding the dried tissue in a mortar, $0.05 \mathrm{~g}$ was resuspended in $20 \mathrm{ml}$ of distilled water and incubated in a shaking bath at $30^{\circ} \mathrm{C}$ for $30 \mathrm{~min}$ according to Corzo \& Niell (1992). The suspension was then filtered (Whatman $\mathrm{GF} / \mathrm{F}$ ), and nitrate and SRP concentrations were determined in the filtrate. Concentrations were expressed by FW ( $\mu \mathrm{mol} \mathrm{g}^{-1} \mathrm{FW}$ ) and as internal concentration
(mM) by referring the number of moles to the water content (FW-dry weight [DW]).

Data analysis. Data presented are means of triplicate tanks (or bottles) for each treatment. For water samples, each replicate was the mean of duplicate analyses for each sample. For tissue samples, 3 to 6 thalli from each tank were analysed separately and the mean for each tank was used as a replicate. Curves were fitted using the software KaleidaGraph (Synergy Software).

\section{RESULTS}

Reducing salinity to $50 \%$ of natural seawater had no significant effect on the growth rate of Fucus vesiculosus or Laminaria digitata, but stimulated the growth of F. serratus by $20 \%$ (Fig. 1). The growth measured in $L$. digitata corresponded to the increase in biomass during the first week only as a deterioration of the thalli was observed thereafter, particularly in $50 \%$ seawater.

The uptake rates of nitrate and phosphate in cultures of Fucus vesiculosus, F. serratus, and Laminaria digitata are shown in Fig. 2. There was an initial phase of rapid uptake, which lasted $3 \mathrm{~d}$ for nitrate and $5 \mathrm{~d}$ for 

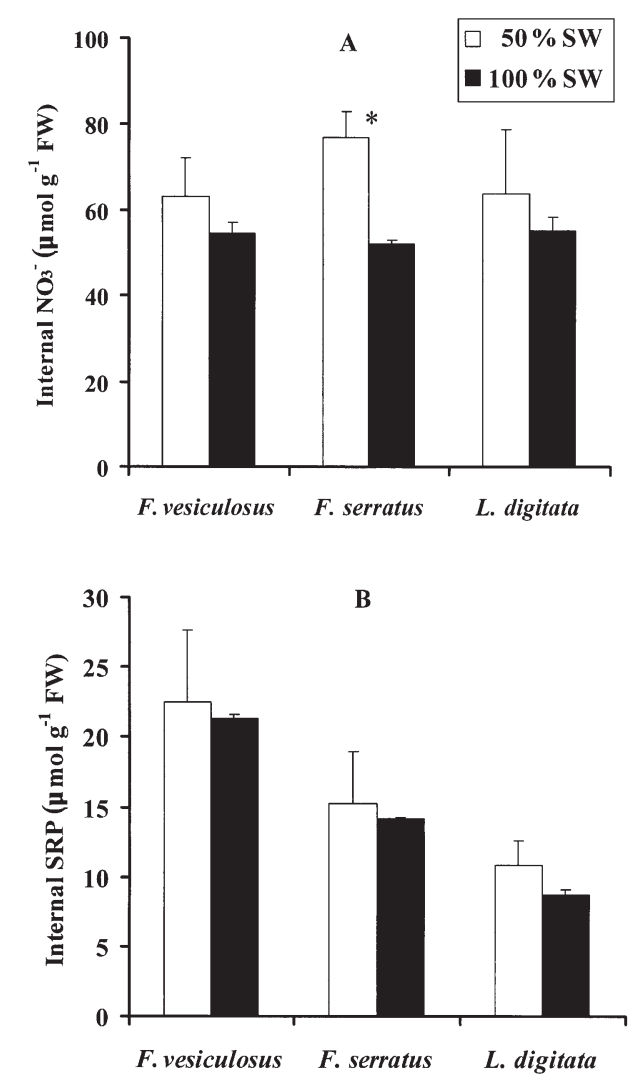

Fig. 3. Internal concentration of (A) nitrate and (B) phosphate in Fucus vesiculosus, F. serratus and Laminaria digitata after $21 \mathrm{~d}$ cultured under $50 \% \mathrm{SW}$ and $100 \% \mathrm{SW}$. * Significant differences $(t$-test, $\mathrm{p}<0.05)$. Data are mean $\pm \mathrm{SD}(\mathrm{n}=6)$

phosphate. After this initial phase, a gradual decline in uptake rates for the Fucus species was observed for the rest of the culture period. In $L$. digitata, however, the uptake rate of nitrate started to decrease after $5 \mathrm{~d}$ in $100 \%$ seawater and after only $2 \mathrm{~h}$ in $50 \%$ seawater. The final steady rates of uptake of nitrate and particularly phosphate were similar in all treatments (except for nitrate uptake in L. digitata), and they ranged from
3.4 to 7.4 and 0.24 to $0.26 \mu \mathrm{mol} \mathrm{g}{ }^{-1} \mathrm{FW} \mathrm{d}^{-1}$ for nitrate and phosphate, respectively.

The internal content of nitrate in Fucus serratus was nearly $40 \%$ higher in $50 \%$ seawater than in $100 \%$ seawater; salinity, however, did not have a significant effect on internal nitrate content of the other 2 species (Fig. 3A). Overall, internal levels of nitrate ranged between 52 and $78 \mu \mathrm{mol} \mathrm{g}{ }^{-1}$ FW. Internal SRP content was highest in F. vesiculosus and lowest in Laminaria digitata, but there was no significant effect of salinity on internal SRP in any species (Fig. 3B).

The ability of algae to remove any substance from the external medium can be shown by the accumulation factor, i.e., the ratio between external and internal concentrations, where the latter is expressed as mmol $\mathrm{l}^{-1}$ internal water (Table 1). The internal nitrate concentration of all 3 species was 600 to 700 times that of the external concentration, and the accumulation factor in Fucus serratus increased significantly when cultured in $50 \%$ seawater. The accumulation factor for phosphate was at least 3 times higher than that for nitrate in all species and was particularly high in F. vesiculosus. The ratio between internal nitrate and phosphate ranged from 2.6 in F. vesiculosus to 6.3 in Laminaria digitata, and lowered salinity increased this ratio in $F$. serratus but had no effect in the other 2 species. The N:P ratio for the uptake rates was 30 to 40 for the Fucus species, but lower in L. digitata because of the decline in nitrate uptake rates with time in this species (Fig. 2).

The rate of uptake of nitrate by Fucus serratus increased with increasing external nitrate concentrations, and saturation was not observed at concentrations as high as $1000 \mu \mathrm{M}$ (Fig. 4A). The maximum uptake rate $\left(V_{\max }\right)$ of $4.4 \mu \mathrm{mol} \mathrm{g}{ }^{-1} \mathrm{FW} \mathrm{h}^{-1}$ and semisaturation constant $\left(K_{0.5}\right)$ value of $714 \mu \mathrm{M}$ were estimated by fitting the data to the Michaelis-Menten model. A different pattern was observed for phosphate uptake (Fig. 4B). Data were best fitted to a double Michaelis-Menten curve, one for concentrations up to

Table 1. Accumulation factor for nitrate and phosphate (soluble reactive phosphate [SRP]) (i.e. the ratio of internal to external concentration) in Fucus vesiculosus, F. serratus and Laminaria digitata cultured in 50 and $100 \%$ seawater (SW), and N:P ratio of internal concentration and of uptake rates. N:P ratios for uptake were calculated from the steady-state uptake rates in Fig. 2. Data are mean \pm standard deviation $(n=3$ to 6$)$. ${ }^{*}$ Significant difference between salinities $(t$-test, $\mathrm{p}<0.05)$

\begin{tabular}{|c|c|c|c|c|c|}
\hline & $\% \mathrm{SW}$ & $\begin{array}{l}\mathrm{NO}_{3}{ }^{-} \text {accumulation } \\
\text { factor }\end{array}$ & $\begin{array}{l}\text { SRP accumulation } \\
\text { factor }\end{array}$ & $\begin{array}{l}\text { Internal } \mathrm{NO}_{3}^{-}: \mathrm{SRP} \\
\text { (mol:mol) }\end{array}$ & $\begin{array}{l}\text { Uptake } \mathrm{NO}_{3}^{-}: \mathrm{SRP} \\
\text { (mol:mol) }\end{array}$ \\
\hline \multirow[t]{2}{*}{ Fucus vesiculosus } & 50 & $839 \pm 122$ & $5977 \pm 980$ & $2.8 \pm 0.4$ & $38.1 \pm 2.4$ \\
\hline & 100 & $727 \pm 32$ & $5666 \pm 96$ & $2.6 \pm 0.1$ & $41.2 \pm 1.6$ \\
\hline \multirow[t]{2}{*}{ Fucus serratus } & 50 & $946 \pm 73^{*}$ & $3740 \pm 917$ & $5.3 \pm 1.3^{*}$ & $32.6 \pm 4.8$ \\
\hline & 100 & $640 \pm 10^{*}$ & $3477 \pm 22$ & $3.7 \pm 0.1^{*}$ & $32.2 \pm 3.6$ \\
\hline \multirow[t]{2}{*}{ Laminaria digitata } & 50 & $776 \pm 183$ & $2634 \pm 437$ & $6.1 \pm 1.9$ & $13.0 \pm 2.3^{*}$ \\
\hline & 100 & $669 \pm 39$ & $2109 \pm 112$ & $6.3 \pm 0.0$ & $21.7 \pm 8.5^{*}$ \\
\hline
\end{tabular}



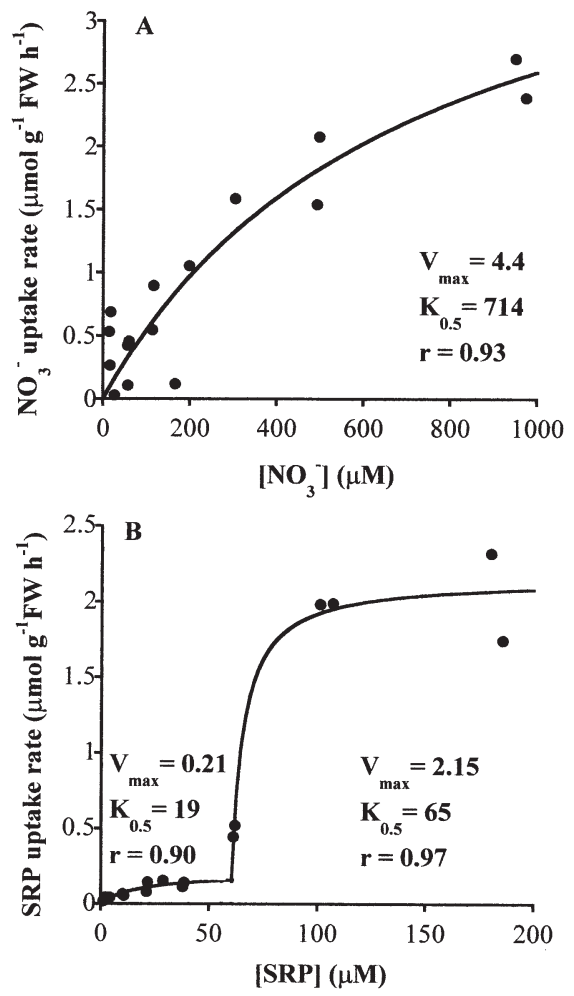

Fig. 4. (A) Nitrate uptake rate by Fucus serratus in $50 \%$ SW as a function of external nitrate concentration, fitted to the hyperbolic Michaelis-Menten equation; (B) phosphate uptake rate as a function of external phosphate concentration, fitted to 2 different Michaelis-Menten equations. Parameters for the fitted curves are given $\left(V_{\max }\right.$ : maximum uptake rate; $K_{0.5}$ : semi-saturation constant); $\mathrm{r}$ is the correlation coefficient (all significant at $\alpha=0.05$ )

$50 \mu \mathrm{M}$ SRP and another one using only concentrations above $50 \mu \mathrm{M}$. Fitting a single Michaelis-Menten curve or a linear relationship gave non- or only weakly significant $r$ values. The $V_{\max }$ value for the higher concentration range was $2.15 \mu \mathrm{mol} \mathrm{g}^{-1} \mathrm{FW} \mathrm{h}^{-1}$, which suggests that under completely saturating concentrations of both nitrate and phosphate, the N:P ratio of uptake $\left(V_{\max } \mathrm{NO}_{3}{ }^{-} / V_{\max } \mathrm{SRP}\right.$ ) would be close to 2 .

When Fucus serratus was cultured in $50 \%$ seawater and exposed to different photoperiods, the rate of uptake of both nitrate and phosphate over $4 \mathrm{~d}$ increased with daylength (Fig. 5A). The increase in uptake rate for nitrate was greater than that for phosphate, so that the resulting $\mathrm{N}: \mathrm{P}$ ratio of uptake increased by 2.5 times between 6 and $18 \mathrm{~h}$ photoperiods. The increase in daylength also led to increased growth rates from 0.3 to $1.7 \%$ of $\mathrm{FW} \mathrm{d}^{-1}$ (Fig. 5B).

The time courses of nitrate and phosphate uptake rates were followed in cultures of Fucus serratus at $50 \%$ seawater for $4 \mathrm{~d}$ (Fig. 6). Both nitrate and phosphate uptake showed a similar pattern. Uptake rates generally decreased during the later hours of darkness
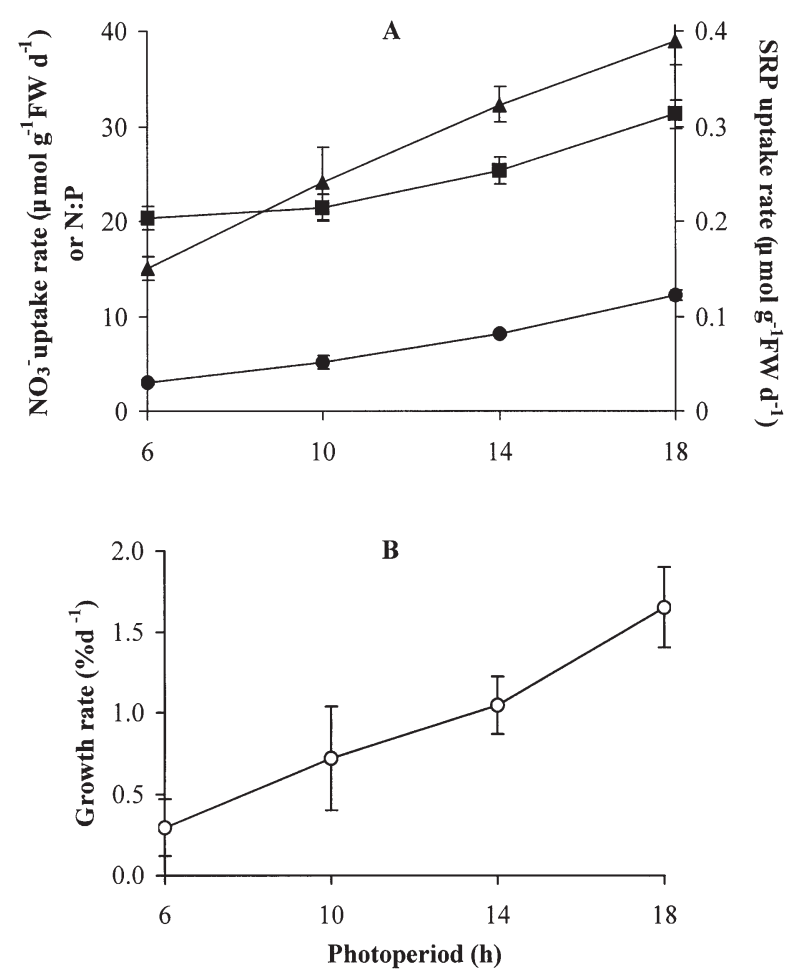

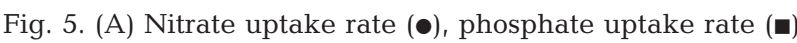
and $\mathrm{NO}_{3}{ }^{-}:$SRP ratio $(\mathbf{\Lambda})$; and (B) growth rate of Fucus serratus cultured in $50 \%$ SW under different photoperiods. Data are mean $\pm \mathrm{SD}(\mathrm{n}=3)$
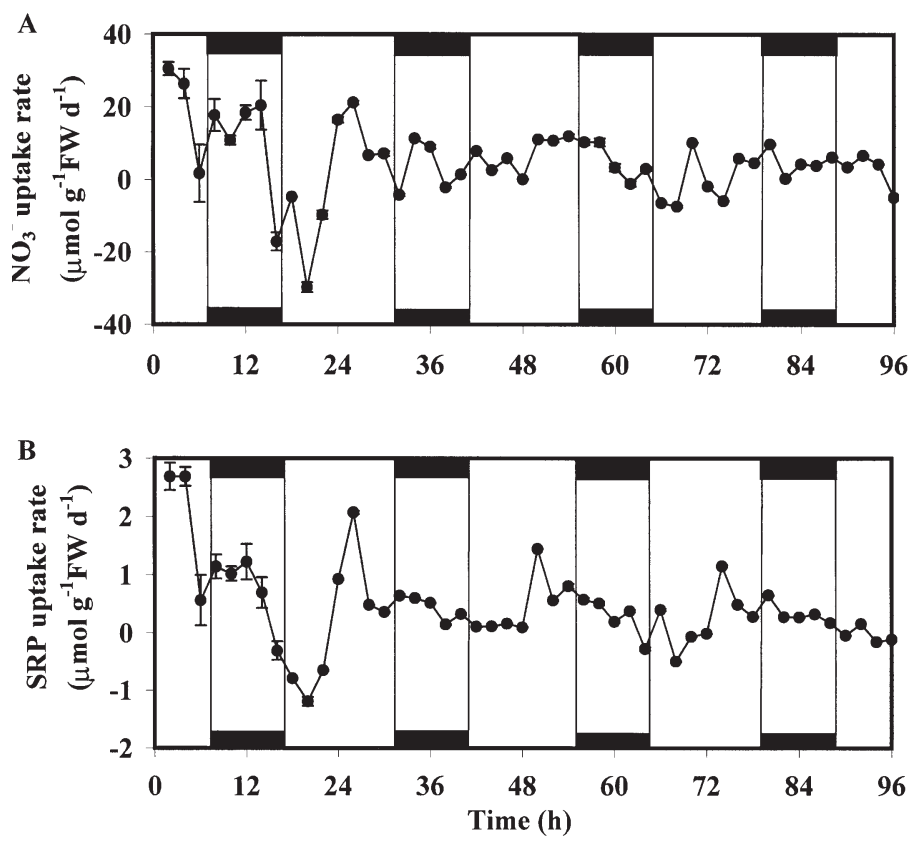

Fig. 6. Diel patterns of (A) nitrate and (B) phosphate uptake by Fucus serratus cultured in $50 \%$ SW. Black rectangles represent the dark period (photoperiod $14 \mathrm{~h}$ light:10 h dark). Data are mean $\pm \mathrm{SD}(\mathrm{n}=3)$ 
and the early light period, and negative values for both nitrate and phosphate uptake were recorded on Days 2 and 4. Uptake rates recovered by the middle of the light period and remained stable until the middle of the dark period. This pattern was very similar under all the different photoperiods (data not shown), although the absolute values of the uptake rates changed with daylength, as described in Fig. 5A.

\section{DISCUSSION}

It is well established that estuarine algae have a broader salinity tolerance than strictly marine algae; additionally, within the marine environment, intertidal species can tolerate low salinity better than sublittoral species (Khfaji \& Norton 1979, Yarish \& Edwards 1982, Hanisak \& Samuel 1987, Russell 1987b). The enhancement of growth rates at low salinity in Fucus vesiculosus and F. serratus (Fig. 1) has been previously reported (Bäck et al. 1992, Strømgren 1994). Increased growth rates at low salinity have also been reported for marine microalgae (Craggs et al. 1994). In the subtidal zone, salinity fluctuations are considerably less than in the intertidal, and tolerance to lowered salinity is expected to be of minor importance (Strømgren 1994). In the present study, Laminaria digitata was observed to grow at $50 \%$ salinity only during the first week, and thereafter visible damage of the thalli was detected, indicating low tolerance of this species to reduced salinity.

The steady uptake rates achieved by both Fucus species after adaptation to culture conditions and nutrient level (Fig. 2) show that these species are able to remove nutrients at both full and half salinity at a constant rate over at least $2 \mathrm{wk}$. Degradation of Laminaria digitata thalli after $7 \mathrm{~d}$, especially at low salinity, could have caused the decrease in the uptake rate for nitrate. The uptake rates for $F$. vesiculosus and $F$. serratus were 6 times lower than those reported in long-term incubation experiments (days) for Scottish marine microalgae (Craggs et al. 1994), and 35 and 66 times lower than for fast-growing macroalgae from East Africa (Haglund \& Lindström 1995) for inorganic N and $\mathrm{P}$, respectively. One of the factors that may be responsible for the lower rates reported here is that the species used in the present experiments have low growth rates (Fig. 3; Wallentinus 1984). Intertidal macroalgae with higher growth rate such as Ulva and Porphyra species are able to reach uptake rates of ca. 150 (Gordillo et al. 2001) and $43 \mu \mathrm{mol} \mathrm{N} \mathrm{g}{ }^{-1} \mathrm{FW} \mathrm{d}^{-1}$ (Mercado et al. 2000), respectively.

The 3 species studied showed an ability to store inorganic N intracellularly under 100 and $50 \%$ salinity conditions (Fig. 3, Table 1). The internal nitrate con- centrations were similar to those reported previously for field-grown Laminaria longicruris (Chapman \& Craigie 1977). The increase in internal nitrate concentration, and hence in the accumulation factor for nitrate observed in Fucus serratus cultured at $50 \%$ seawater, may be related to a general increase in $\mathrm{N}$ metabolism reported for this species when cultured at low salinity (Munda \& Kremer 1977). This strategy is consistent with the generally increased availability of $\mathrm{N}$ in an estuarine habitat resulting from freshwater run-off from land. The removal of nutrients from the medium is not always entirely due to direct incorporation into new algal biomass. In steady-state, the removal of $\mathrm{N}$ and $\mathrm{P}$ would correspond to incorporation into organic components plus accumulation of the inorganic nutrients in the vacuoles of the biomass being created. This would allow algae to assimilate nutrients over periods of low concentrations in their external environment. Faster uptake at the beginning of the culture period would correspond to accumulation in vacuoles, until their storage capacity reaches saturation. The time required to reach such saturation would account for the delay observed in achieving a steady-state for the uptake of each nutrient (Fig. 2). A higher use of internal nitrate than of internal phosphate to synthesise organic components could be responsible for the lower $\mathrm{N}: \mathrm{P}$ ratio for internal concentrations than for uptake rates (Table 1).

Further evidence for the ability of Fucus serratus to adapt to a low salinity and nutrient-enriched environment is found in the relation between nutrient uptake and external nutrient concentration (Fig. 4A). The nitrate uptake mechanism was not saturated even at $1000 \mu \mathrm{M}$, while the high $K_{0.5}$ value suggests a strategy to fill the internal pool when episodic discharges of freshwater with high nitrate content occur. It is assumed that the internal nitrate becomes available for use when external concentrations are low.

Non-saturating and biphasic uptake kinetics have been observed in coastal phytoplankton assemblages, which normally bloom under conditions of high nutrient fluxes and turbulent mixing and are considered to be mechanisms of adaptation to such environments (Collos et al. 1997, Lomas \& Glibert 1999). Furthermore, non-saturating nutrient uptake kinetics have been reported for several macroalgae, including Fucus vesiculosus, by Wallentinus (1984).

The strategy of Fucus serratus to deal with high external phosphate is the activation of a second mechanism, apparently different from the high affinity one operating at low concentrations (Fig. 4B). These adaptations would make the N:P ratio for uptake drop from values around 30 at relatively subsaturating nutrient levels (Table 1) to values more in accordance with internal inorganic $\mathrm{N}: \mathrm{P}$ ratios when internal pools are 
saturated (Table 1). The uptake of phosphate at concentrations below $50 \mu \mathrm{M}$ SRP yielded $V_{\max }$ and $K_{0.5}$ values similar to those reported by Hurd \& Dring (1990) for the same species. The highest concentration used by these authors was $25 \mu \mathrm{M} \mathrm{SRP}$, so that the mechanism operating at high concentrations was not detected. Since common assay concentrations are rarely above $30 \mu \mathrm{M}$ for both $\mathrm{N}$ and SRP, Lomas \& Glibert (1999) have suggested, from their results with phytoplankton, that more non-saturating and biphasic uptake kinetics may be found in algae of coastal areas if researchers use a wider range of concentrations in their assays. For example, biphasic kinetics was observed in the red alga Gracilaria gaditana when inorganic carbon uptake was investigated at high $\mathrm{CO}_{2}$ levels (Andría et al. 1999).

The nitrate and phosphate uptake mechanisms operating at low salinity were affected by the availability of light energy. This feature is particularly relevant for Fucus species, because they are active in their natural environment all year round and live through the marked changes in photoperiod that occur in northern European latitudes (from $6 \mathrm{~h}$ light:18 h dark to $18 \mathrm{~h}$ light:6 $\mathrm{h}$ dark). Changes in uptake rates with daylength correlated well with changes in growth rate (Fig. 5), suggesting that nitrate and phosphate uptake was modulated by the growth rate. During the diel cycle, the reduction of nutrient uptake at the end of the dark period and the beginning of the light period (Fig. 6) may indicate a mechanism in which cellular energy is differentially distributed between nitrate and phosphate uptake mechanisms on one side and carbon uptake and fixation on the other, depending on the time of the day. This strategy has been suggested by Falkowski (1975), Keller \& Paerl (1980), Lean et al. (1982) and Turpin (1983) for some microalgal species. In our example, both the temporal partitioning of $\mathrm{C}$ and nutrients, and the ability to maintain nutrient uptake in darkness are consistent with a mechanism that reacts to the changing availability of these nutrients in an intertidal habitat. A temporal partitioning of $\mathrm{C}$ and $\mathrm{N}$ metabolism at low salinity has been reported for F. distichus (Rueter \& Robinson 1986). Nitrate uptake operating in both light and darkness has also been reported for F. spiralis (Topinka 1978).

Batch cultures of macroalgae at low salinity are a helpful tool for establishing, at least in part, the optimal conditions for mass cultures of algae (Fábregas et al. 1984 , 1985) that can be used for sewage treatment. Treatment with macroalgae is now becoming an alternative to microalgae, but care must be taken when extrapolating pilot plant results to a larger scale. Results from this study show that the intertidal species Fucus vesiculosus and F. serratus have the ability to adapt to high nutrient concentrations and low salinity and are therefore suitable candidates for wastewater treatment, while the subtidal Laminaria digitata would be a less suitable species. The advantages of Fucus species over faster-growing macroalgae, such as Ulva species, are that they are abundant on NW European coasts during the whole year and are easier to maintain in long-term cultures.

Acknowledgements. This work was financed by the Natural Environment Research Council of the United Kingdom (project GR3/CO032).

\section{LITERATURE CITED}

Andría JR, Pérez-Lloréns JL, Vergara JJ (1999) Mechanisms of inorganic carbon acquisition in Gracilaria gaditana nom. prov. (Rhodophyta). Planta 208:564-573

Bäck S, Collins JC, Russell G (1992) Effects of salinity on growth of Baltic and Atlantic Fucus vesiculosus. Br Phycol J 27:39-47

Chapman ARO, Craigie JS (1977) Seasonal growth in Laminaria longicruris: relation with dissolved inorganic nutrients and internal reserves of nitrogen. Mar Biol 40:197-205

Collos Y, Vaquer A, Bibent B, Slawyk G, García N, Souchu P (1997) Variability in nitrate uptake kinetics of phytoplankton communities in a Mediterranean coastal lagoon. Estuar Coast Shelf Sci 44:369-375

Corzo A, Niell FX (1992) Inorganic nitrogen metabolism in Ulva rigida illuminated with blue light. Mar Biol 112: 223-228

Craggs RJ, McAuley PJ, Smith VJ (1994) Batch culture screening of marine microalgal nutrient removal from primary sewage effluent. Hydrobiologia 288:157-166

DeBusk TA, Blakeslee M, Ryther JH (1986) Studies on the outdoor cultivation of Ulva lactuca L. Bot Mar 29:381-386

Fábregas J, Abalde J, Herrero C, Cabezas B, Veiga M (1984) Growth of the marine microalga Tetraselmis suecica in batch cultures with different salinities and nutrient concentrations. Aquaculture 42:207-215

Fábregas J, Herrero C, Abalde J, Cabezas B (1985) Growth, chlorophyll $a$ and protein of the marine microalga Isochrysis galbana in batch cultures with different salinities and high nutrient concentrations. Aquaculture 50:1-11

Falkowski PA (1975) Nitrate uptake in marine phytoplankton: comparison of half-saturation constants from seven species. Limnol Oceanogr 20:412-416

Gordillo FJL, Niell FX, Figueroa FL (2001) Non-photosynthetic enhancement of growth by high $\mathrm{CO}_{2}$ level in the nitrophilic seaweed Ulva rigida C. Agardh (Chlorophyta). Planta 213:64-71

Haglund K, Lindström J (1995) The potential use of macroalgae for removal of nutrients from sewage water in East Africa. Ambio 24:510-512

Haglund K, Pedersen M (1992) Growth of the red alga Gracilaria tenuistipitata in brackish water in Sweden. Growth, nutrient uptake, co-cultivation with rainbow trout and epiphyte control. J Appl Phycol 5:271-284

Hanisak MD, Samuel MA (1987) Growth rates in culture of several species of Sargassum from Florida, USA. Hydrobiologia 151/152:399-404

Hurd CL, Dring MJ (1990) Phosphate uptake by intertidal algae in relation to zonation and season. Mar Biol 107:281-289

Keller P, Paerl H (1980) Physiological adaptation and re- 
sponse to environmental stress during an $\mathrm{N}_{2}$ fixing Anabaena bloom. Appl Environ Microbiol 40:587-595

Khfaji AK, Norton TA (1979) The effects of salinity on the distribution of Fucus ceranoides. Estuar Coast Mar Sci 8: 433-439

Lean DRS, Murphy TP, Pick FR (1982) Photosynthetic response of lake plankton to combined nitrogen enrichment. J Phycol 18:509-521

Lomas MW, Glibert PM (1999) Temperature regulation of nitrate uptake: a novel hypothesis about nitrate uptake and reduction in cool-water diatoms. Limnol Oceanogr 44: 556-572

Mercado JM, Gordillo FJL, Figueroa FL, Niell FX (1999) Effects of different levels of $\mathrm{CO}_{2}$ on photosynthesis and cell components of the red alga Porphyra leucosticta. J Appl Phycol 11:455-461

Munda IM (1964) Observations on variations in form and chemical composition of Fucus ceranoids L. Nova Hedwigia 8:403-414

Munda IM, Kremer BP (1977) Chemical composition and physiological properties of fucoids under conditions of reduced salinity. Mar Biol 42:9-15

Murphy J, Riley JP (1962) Modified single solution method for the determination of phosphate in natural waters. Anal Chim Acta 27:31-36

Rueter JG, Robinson DH (1986) Inhibition of carbon uptake and stimulation of nitrate uptake at low salinities in Fucus distichus (Phaeophyta). J Phycol 22:243-246

Russell G (1987a) Salinity and seaweed vegetation. In: Craw-

Editorial responsibility: Otto Kinne (Editor),

Oldendorf/Luhe, Germany ford RMM (ed) Plant life in aquatic and amphibious habitats. Blackwell, Oxford, p 35-52

Russell G (1987b) Spatial and environmental components of evolutionary change: interactive effects of salinity and temperature on Fucus vesiculosus as an example. Helgol Meeresunters 41:371-376

Sharp JH (1983) The distribution of inorganic nitrogen and dissolved and particulate organic nitrogen in the sea. In: Carpenter EJ, Capone DG (eds) Nitrogen in the marine environment. Academic Press, New York, p 1-35

Strømgren T (1994) Apical elongation of fucoid algae exposed to low salinities. Aquat Bot 49:67-74

Topinka J (1978) Nitrogen uptake by Fucus spiralis (Phaeophyceae). J Phycol 14:244-247

Turpin DH (1983) Ammonium induced photosynthetic suppression in ammonium limited Dunaliella tertiolecta (Chlorophyta). J Phycol 19:70-76

Vandermeulen H, Gordin H (1990) Ammonium uptake using Ulva (Chlorophyta) in intensive fishpond systems: mass culture and treatment of effluent. J Appl Phycol 2:363-374

Wallentinus I (1984) Comparison of nutrient uptake rates for Baltic macroalgae with different thallus morphologies. Mar Biol 80:215-225

Wood ED, Armstrong FAJ, Richards FA (1967) Determination of nitrate in sea water by cadmium-copper reduction to nitrite. J Mar Biol Assoc UK 47:23-31

Yarish C, Edwards P (1982) A field and cultural investigation of the horizontal and seasonal distribution of estuarine red algae of New Jersey. Phycologia 21:112-124

Submitted: March 29, 2001; Accepted: December 4, 2001 Proofs received from author(s): May 7, 2002 